\title{
Oceanographical Expedition of the Dana, I928-1930.
}

By Prof. Johannes Schmidt, Ph.D., D.Sc.,

Carlsberg Laboratory, Copenhagen, Leader of the Expedition.

IN Nature of Dec. 29, 1928, Prof. D'Arcy W. Thompson gave an outline of the plans and scope of this expedition on board the Royal Danish Research Ship Dana. This vessel, with its ex. perienced master, Captain G. Hansen, and staffed by officers of the Royal Navy, was placed at the disposal of the expedition by the Danish Government. The cost of the expedition however, was
Admiral H.R.H. Prince Valdemar of Denmark was patron of the expedition, and it was controlled by a committee, the presidents of which were the late Prof. C. H. Ostenfeld and Prof. A. B. Drachmann, president of the Carlsberg Foundation; G. C. Amdrup, Vice-Admiral of the Royal Danish Navy, was vice-president of the committee.

It was my good fortune to have among the

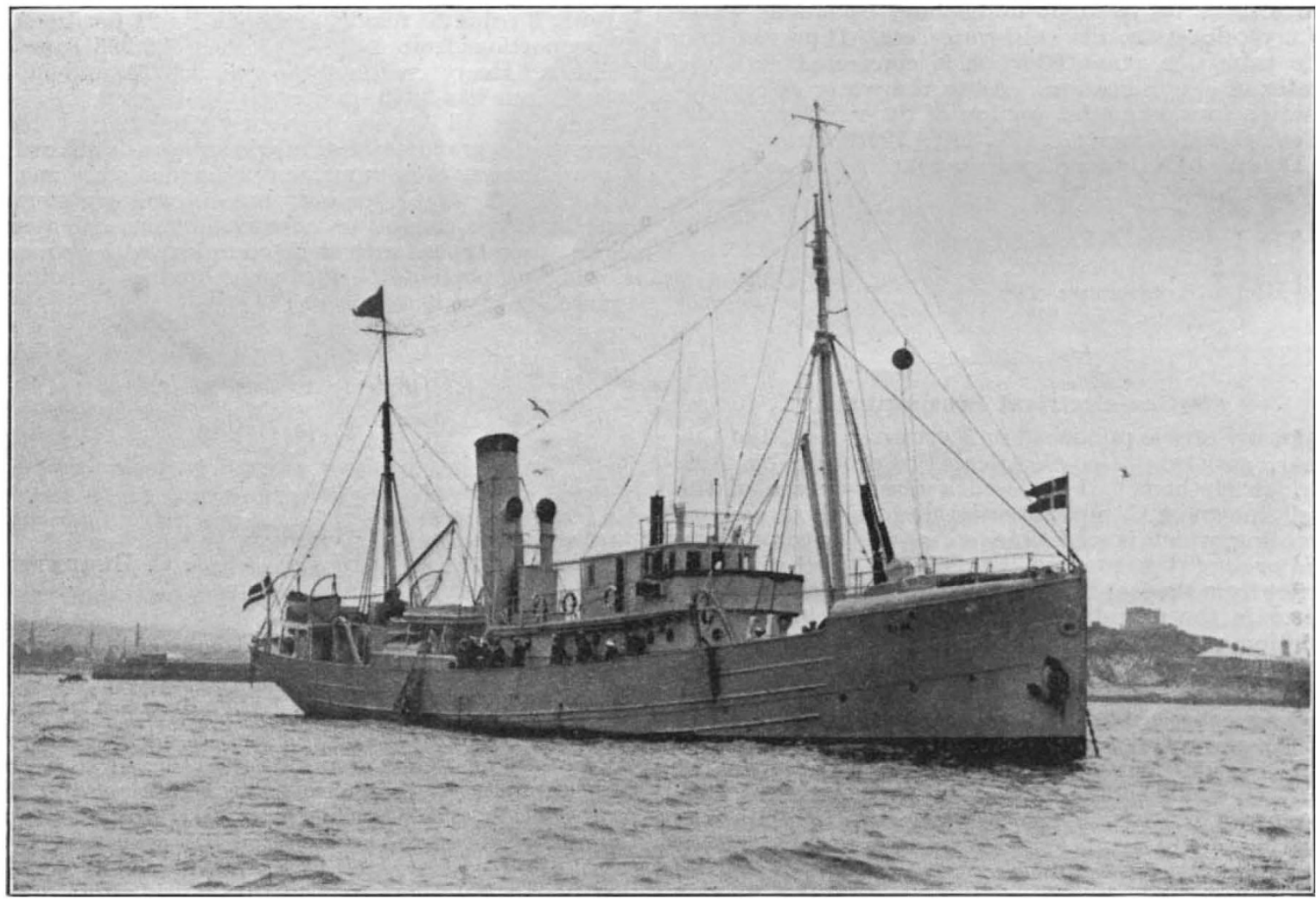

Photo.]

FIG. 1.-Royal Danish Research Ship Dana (360 tons), at anchor in Plymouth Roads, June 21, 1930, on her return from the

[The Times. circumnavigation expedition.

defrayed by the Carlsberg Foundation, the largest scientific fund in Denmark; hence the official title: "The Carlsberg Foundation's Oceanographical Expedition round the World 1928-30 under the Leadership of Professor Johannes Schmidt".

Prof. D'Arcy Thompson has already noted in detail one of the main tasks of the expedition, namely, an investigation of the life-history of the Indo-Pacific fresh-water eels (Anguilla), in similar fashion to the work I had already carried out in the case of the North Atlantic fresh-water eels. What I propose to do here is to give a brief account of the main points in the working methods and plans of the expedition, and then give two illustrations of the results, one drawn from the biological side, the other from the hydrographic side; the latter has been prepared by my colleague, Mr. Helge Thomsen. scientific workers several colleagues from my earlier expeditions, the zoologists Dr. P. Jespersen, Dr. $\AA$. V. Tảning, and Mr. A. F. Bruun, the physicists Dr. J. N. Nielsen and Mr. Helge Thomsen, and the botanist Prof. Ove Paulsen; the botanist Mr. E. Nielsen also took part in the expedition. Further, two Danish zoologists, Dr. Th. Mortensen and Dr. R. Spärck, spent some time on board engaged in bottom work, the former at St. Helena and the Canaries, the latter in the Mediterranean.

The expedition occupied two years. The Dana left Copenhagen on June 14, 1928, and after circling the globe in a westerly direction, returned home on June 30,1930 . The total number of stations amounted to 661 , and the distance covered was 65,000 miles, with a coal consumption of 3358 tons. It should be mentioned that the 
Dana, through her short-wave radio station, was in direct communication with the Copenhagen station during the whole expedition; even at the

to those of the Challenger expedition, in which the pelagic collections played a more subordinate part.

The most characteristic features of the working

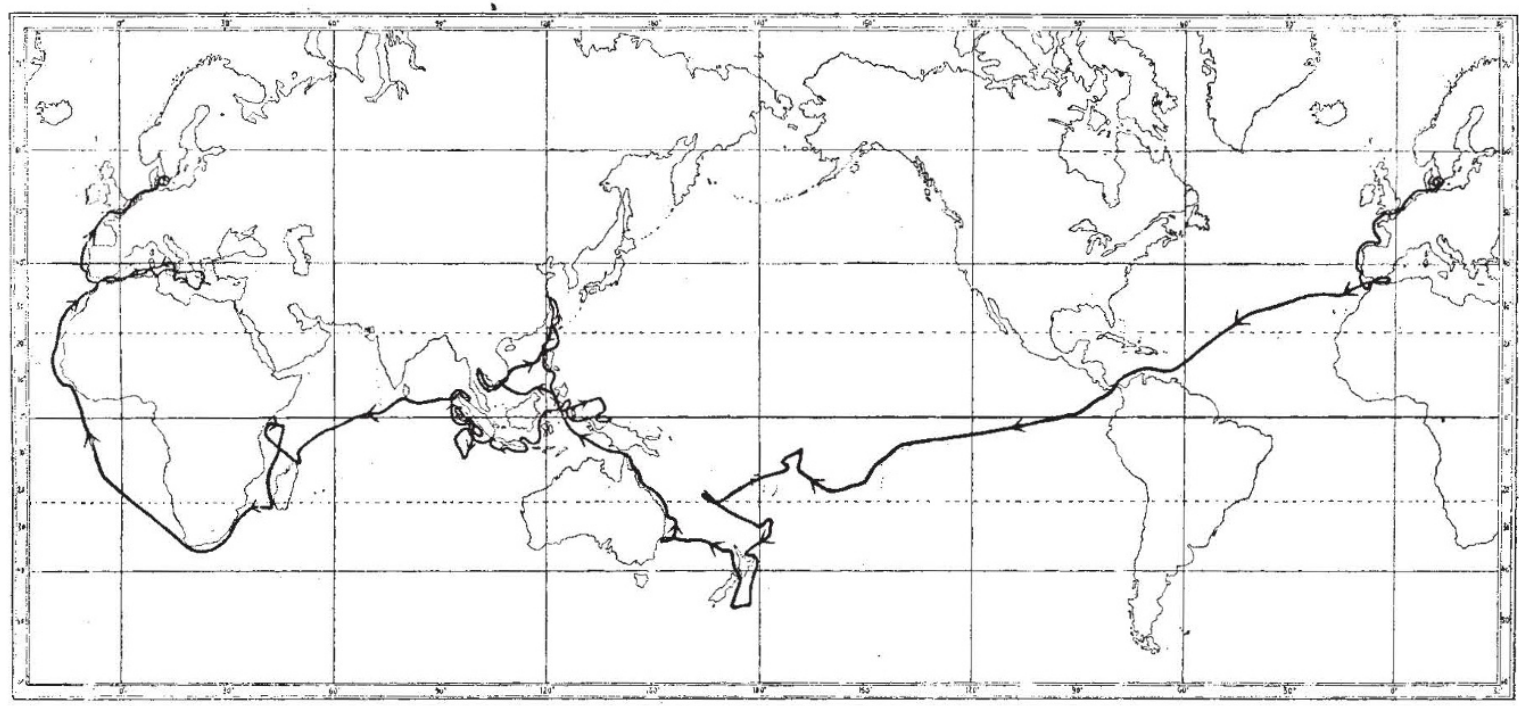

Fig. 2,-Route of the Dana round the world, June 14, 1928-June 30, 1930.

antipodal region near New Zealand the communication was perfect.

The route mapped with regard to the eel investigations was carried out almost completely according to plan; but owing to the limited coal capacity of our small vessel, we did not succeed in visiting all the regions in the Pacific and Indian Oceans that had been included in the scheme. The chart (Fig. 2) shows the course of the Dana round the world. It ran in the main parallel with the equator, except in the western Pacific and on the last lap, where it turned vertical to the $b$ equator from the Cape of Good Hope homewards.

The object of the expedition was not to bring home collections of zoological rareties. The main general task was to study the distribution of the commonest oceanic species and genera in the three great oceans, and-having regard for the physical and chemical conditions under which they live-to seek some understanding of the factors concerned in this actual distribution and to make some contribution to their life-histories.

Whilst the expedition of the Dana's great predecessor, the Challenger, was chiefly concerned with the investigation of the bottom and its fauna, our expedition was in special degree a pelagic expedition. We investigated especially the upper and middle water layers and their inhabitants, and as we had the best pelagic fishing apparatus of the present time at our disposal, I venture to hope that our results will form, to a not inconsiderable extent, a supplement methods and plans of the Dana expedition may be summarised in three groups :

1. With the aid of the most efficient apparatus, to obtain a very large material, rich in individuals,
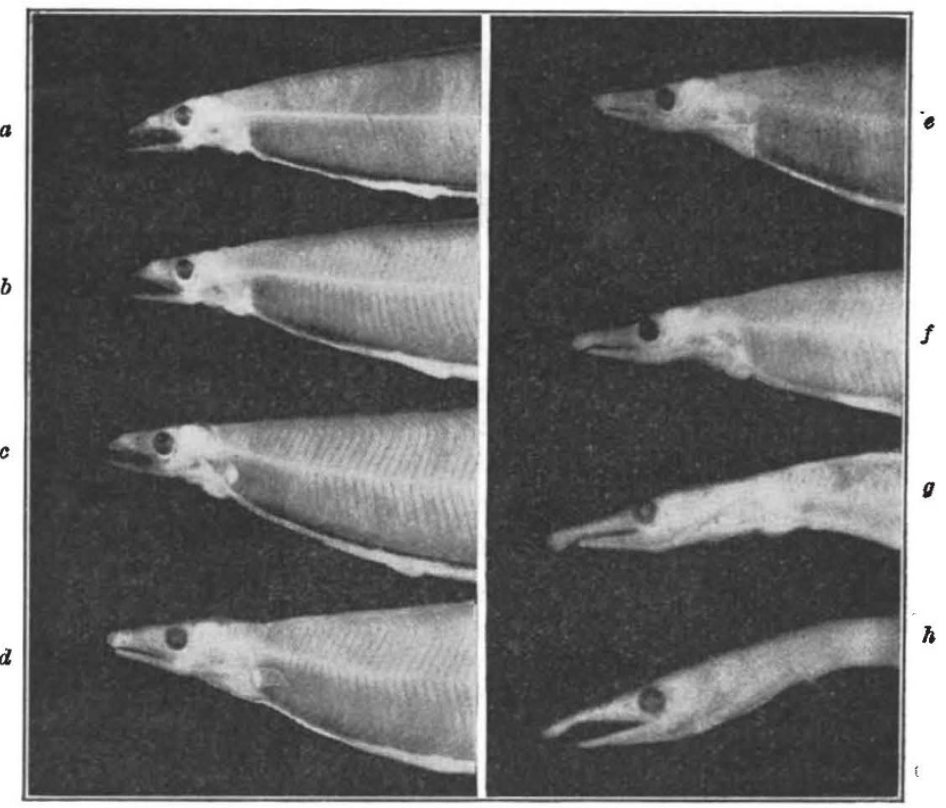

Fua. 3.-Metamorphosis of Nessorhamphus ingolfianus, Johs. Schmidt. Specimens from the Sargasso Sea, showing transformation from the larval to the eel stage. Photo A. F. Bruun.

a. Larval stage $67 \mathrm{~mm}$.

b. Metamorphosis stage $71 \mathrm{~mm}$.

c. , ,,$\quad 77 \mathrm{~mm}$

e. Metamorphosis stage $84 \mathrm{~mm}$.

f. " " $\quad 78.5 \mathrm{~mm}$.

$\begin{array}{llll}g . & \text { h. } & \text { " } & \end{array}$

No. 3203, VoL. 127]

of the pelagic life in the different depths of the various oceans.

2. With the aid of simultaneous, methodical 
investigations on the physical and chemical composition of the different water layers, to obtain data which would permit us to conclude under what environmental conditions each single one of the millions of pelagic organisms, taken in our nets, may live.

3. By means of the large pelagic material, which in numerical richness of the single species presumably surpasses that of earlier expeditions round the world, to subject a number of important oceanic species or genera to a finer analysis, with reference to classification, than has previously been possible with the frequently somewhat scanty material available from the distant waters. To supplement the third point, I may add that the investigations of recent years, inter alia those especially of the fresh-water eels, have shown that the treatment of the life-history of a form (in part also of its distribution) must descend to the lowest systematic units. But these units cannot be reached, as a rule, unless one has a large material of individuals, on which one can use biometric methods similar to those applied by Heincke and others to various northern food-fishes, and which I have myself used for a number of years in the series of " Racial Investigations " published by the Carlsberg Laboratory since 1917.

I nourish, therefore, the hope that our large and rich material from the three oceans, dealt with in this manner and from this point of view, may contribute new and important information regarding the species and genera of the pelagic fauna, their distribution in the oceans, their dependence on environmental conditions, and their life-histories. $I$ refer here specially to the fishes which seem in marked degree suitable to biometric treatment, not least because the numerous larvæ can often be included in the investigation-several of the principal characters for the finer analysis, such as number of fin rays and especially vertebræ, being already fixed in the larval stage. In addition, my assistants, several of whom took part in the expedition, are well acquainted with these investigations, each in his own group-I may mention here Dr. A. V. Táning, whose work on the specifically and individually rich group of Scopelids has already won general recognition.

The expedition's field of operations embraced not only the three oceans, but also many of the principal enclosed seas ; Mediterranean, Caribbean, Banda, Celebes, Sulu and Mindanao, and the China Seas. The following table summarises the number of the principal pelagic and hydrographical operations, etc., in the three oceans:

\begin{tabular}{|c|r|r|r|r|}
\hline & $\begin{array}{c}\text { South } \\
\text { Pacific. }\end{array}$ & $\begin{array}{r}\text { North } \\
\text { Pacific. }\end{array}$ & $\begin{array}{r}\text { Indian } \\
\text { Ocean. }\end{array}$ & Atlantic. \\
\hline $\begin{array}{c}\text { Horizontal hauls } \\
\text { with large pe- }\end{array}$ & 606 & 377 & 1046 & 1034 \\
lagic nets. & & & \\
$\begin{array}{c}\text { Vertical hauls } \\
\text { with silk nets }\end{array}$ & 162 & 97 & 74 & 161 \\
$\begin{array}{c}\text { Deep sea water } \\
\text { samples }\end{array}$ & 1110 & 763 & 917 & 1383 \\
Echo soundings & 2025 & 896 & 2215 & 3064 \\
\hline
\end{tabular}

It will naturally take some time before the large amount of material can be worked out fully, but a few examples of the results of the expedition may already be given.

(To be continued.)

\section{Centenary of William Symington.}

By Eng.-Capt. Edqar C. Smith, O.B.E., R.N.

$\mathrm{T}$ $\mathrm{EE}$ invention of the steam boat, or rather the application of the steam engine to the propulsion of vessels, the successful solution of which involved many problems, will always remain one of the great landmarks of human progress. On no other single project of the same nature, perhaps, was time and thought, energy and wealth, expended so lavishly, and the recognition of the labours of its inventors is, therefore, a moral obligation. Many of the projectors of steam navigation are known to us only by their patents or pamphlets, some are remembered for their ingenious suggestions and inventions, and a few by their persistent efforts to achieve what the majority of their fellows thought impractioable. "Crazy Rumsey" and "Fulton's Folly" are but two of the epithets which remind us of the scepticism the pioneers had to face. But neither derision nor opposition, failure nor disappointment, losis of health nor wealth, could stay the hand of progress. There was always someone to step into the ranks to take the place of the fallen until the final goal was reached.

"Generally what is usually called an invention", said the late Sir Charles Parsons, "is the work of many individuals - each one adding something to the work of his predecessors." This was true only to a limited extent in the case of the steam boat, for the experiments of the Marquis de Jouffroy in France, of Fitch, Rumsey, Stevens, and Fulton in the United States, and of Miller, Symington, Stanhope, and Bell in Great Britain, were largely independent of each other. Steam navigation as a regular means of transport is usually associated with the Clermont of Fulton and the Comet of Bell, built respectively in 1807 and 18.12, but, as a matter of fact, the problem had already been completely solved in 1802 by Symington when he engined the Charlotte Dundas, and it was a cruel stroke of fate which robbed him of the fame which should have made him known as the 'father of steam navigation'. The machinery he placed in the Charlotte Dundas was not surpassed in simplicity and suitability for fifty years; it was far superior to that used by any of his predecessors, or even that supplied by the famous firm of Boulton and Watt for Fulton's Clermont. If, therefore, he is denied the title of the 'father of steam navigation', no one can withhold from him the name of the ' father of marine engineering'.

Symington, the centenary of whose death occurs on Mar. 22, was born in the mining village of Lead(Continued on p. 455.)

No. 3203, VoL. 127] 